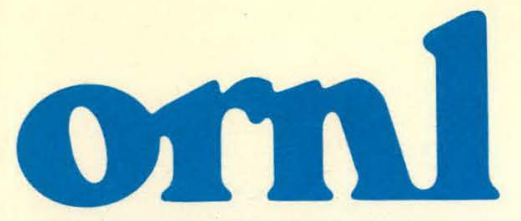

OAK RIDGE NATIONAL LABORATORY

UNION CARBIDE

\title{
Radioactive Waste Disposal Areas and Associated Environmental Surveillance Data at Oak Ridge National Laboratory
}

Thomas W. Oakes Kenneth E. Shank 


\section{DISCLAIMER}

This report was prepared as an account of work sponsored by an agency of the United States Government. Neither the United States Government nor any agency Thereof, nor any of their employees, makes any warranty, express or implied, or assumes any legal liability or responsibility for the accuracy, completeness, or usefulness of any information, apparatus, product, or process disclosed, or represents that its use would not infringe privately owned rights. Reference herein to any specific commercial product, process, or service by trade name, trademark, manufacturer, or otherwise does not necessarily constitute or imply its endorsement, recommendation, or favoring by the United States Government or any agency thereof. The views and opinions of authors expressed herein do not necessarily state or reflect those of the United States Government or any agency thereof. 


\section{DISCLAIMER}

Portions of this document may be illegible in electronic image products. Images are produced from the best available original document. 
Printed in the United States of America. Available from National Technical Information Service

U.S. Department of Commerce

5285 Port Royal Road, Springfield, Virginia 22161

NTIS price codes-Printed Copy: A03; Microfiche A01

This report was prepared as an account of work sponsored by an agency of the United States Government. Neither the United States nor any agency thereof, nor any of their employees, makes any warranty, expressed or implied, or assumes any legal liability or responsibility for any third party's use or the results of such use of any information, apparatus, product or process disclosed in this report, or iepiesents that itc use by such third party would not infringe privately owned rights. 


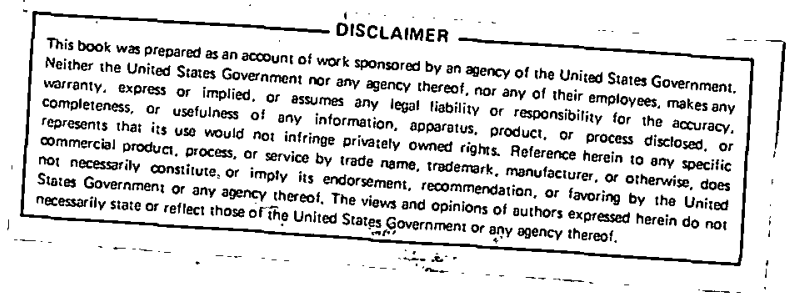

ORNL/TM-6893

Contract No. W-7405-eng-26

Environmental Surveillance and Evaluation Section

INDUSTRIAL SAFETY AND APPLIED HEALTH PHYSICS DIVISION

RADIOACTIVE WASTE DISPOSAL AREAS AND ASSOCIATED ENVIRONMENTAL SURVEILLANCE DATA AT OAK RIDGE NATIONAL IAABORATORY

Thomas W. Oakes and Kenneth E. Sharik

Date Published - December 1979

\author{
OAK RIDGE NATIONAL LABORATORY \\ Oak Ridge, Tennessee 37830 \\ operated by \\ UNION CARBIDE CORPORATION \\ for the \\ DE'PARTMENT OF ENERGY
}




\section{THIS PAGE \\ WAS INTENTIONALLY \\ LEFT BLANK}


CONTENTS

Page

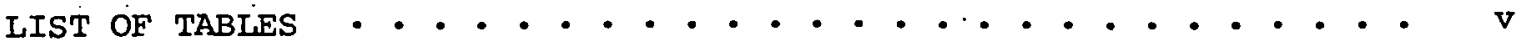
LIST OF FIGURES . . . . . . . . . . . . . . . . . . . vii HIGHLIGHTS . . . . . . . . . . . . . . . . . . 1 INTRODUCTION .......................... 2 SOURCES OF CONTAMINATION. ..................... 4

SRWDA No. 1 ..................... 4

SRWDA No. 2 ...................... 4

SRWDA No. 3 .................... 5

SRWDA No. 4 ...................... 6

SRWDA No. 5 ................... 7

SRWDA NO. 6 ...................... 8

Floodplain Areas ................... 8

Waste Ponds . . . . . . . . . . . . . . . 9

Seepage Pits and Trenches . . . . . . . . . . . . 9

WATER SAMPLING . . . . . . . . . . . . . . . . . 10

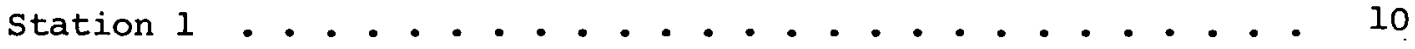

Station 2..................... 10

Station 3 .................... 10

Station 4 ................... 10

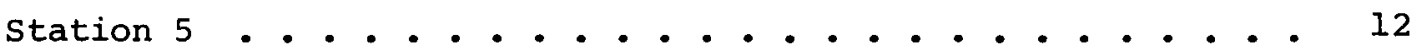

ORGDP Water Sampling Station............. 13

Center's Ferry Sampling Station ............. 20

Melton Hill Dam Sampling Station ............ 22

OTHER ENVIRONMENTAL ANALYSIS . . . . . . . . . . . . . . 23

Fish Sampling . . . . . . . . . . . . . . . . 23

Sediment Sampling . . . . . . . . . . . . . 23

CONCLUSIONS . . . . . . . . . . . . . . . . . . . 25

REFERENCES •.............................. . . . 27 


\section{THIS PAGE}

\section{WAS INTENTIONALLY}

LEFT BLANK 
1 Operational status of ORNL radioactive solid-waste storage area . . . . . . . . . 2

2 Strontium-90 discharges versus precipitation . • . 7

3 Annual discharges of ${ }^{106} \mathrm{Ru}$ to the Clinch River . . 9

4 Annual discharges of radionuclides to the Clinch River, 1949 to 1978 . . . . . . . . . . 14

5 Total amount of radionuclides discharged into Clinch River, 1949 to 1978 . . . . . . . . 17

6 Total percent $\mathrm{MPC}_{\mathrm{w}}$ in the Clinch River . . . . . 20 
THIS PAGE

WAS INTENTIONALLY

LEFT BLANK 
1 Solid-waste disposal areas and water sampling stations at ORNL . . . . . . . . . . . . . . . . 3

2 Water monitoring locations in the Clinch River . . . . 11

3 Percent of $\mathrm{MPC}_{\mathrm{w}}$ total over White oak Dam . . . . . . 15

4 Percent of MPC $_{w}$ total for dilution calculation in the Clinch River ${ }^{W}$............... 16

5. Tritium releases to the Clinch River (3-yr. intervals) • . 18

6 Percent of $\mathrm{MPC}_{\mathrm{w}}$ total at the ORGDP intake . . . . . . 19

7 Percent of $\mathrm{MPC}_{\mathrm{w}}$ total at Kingston, Tennessee . . . . . 21

8 Cesium-137 in river silt (1967) . . . . . . . . . 24 
RADIOACTIVE WASTE DISPOSAL AREAS AND ASSOCIATED ENVIRONMENTAL

SURVEILLANCE DATA AT OAK RIDGE NATIONAL LABORATORY

Thomas W. Oakes and Kenneth E. Shank

HIGHLIGHTS

Environmental surveillance data have been collected around radioactive waste disposal areas for the past thirty years at Oak Ridge National Laboratory (ORNL). The wealth of data collected around the ORNL radioactive waste burial grounds is presented in this review. The purpose of this paper is to describe the solid waste burial grounds in detail along with the environmental monitoring data. The various monitoring systems are reviewed, and the liquid discharge trends are discussed.

At ORNL, White Oak Creek and Melton Branch tributary surface streams flow through the reservation and receive treated low-level radioactive liquid waste which originates from various Laboratory operations. The streams receive additional low-level liquid waste generated by seepage of radioactive materials from solid-waste burial grounds and intermediate-level liquid-waste sites. Over the years, various liquid-waste treatment and disposal processes have been employed at ORNL; some of these processes have included: settling basins, impoundment, storage tanks, evaporation, ground disposal in trenches and pits, and hydrofracture. Burial of solid radioactive waste was initiated in the early 1940's, and there are six burial grounds at ORNL with two currently in use. Seven trenches were used in the past for intermediate-level liquid-waste disposal.

Monitoring at White Oak Dam, the last liquid control point for the Laboratory, was started in the late 1940's and is continuing. Presently, a network of five environmental monitoring stations is in operation to monitor the radionuclide content of surface waters in the white oak creek watershed.

Facts observed during the lifetime of the disposal sites include:

1. A large amount of ${ }^{106}$ Ru was released during 1959-1964 due to the fact that Conasauga shale did not retain this element as well as it retained other radionuclides.

2. Large quantities of tritiated water have been released to the Clinch River in recent years, but, from a practical standpoint, little can be done to inhibit or control these releases.

3. A general downward trend in the number of curies released has been observed for all other radionuclides.

$A$ number of corrective measures that have been initiated at ORNL to reduce the radioactive liquid discharges are outlined in the paper. 
INTRODUCTION

Six solid radioactive waste disposal areas (SRWDA) have been used since the operation of Oak Ridge National Laboratory (ORNL) began in 1943. The location of these SRWDA's are shown in Figure 1 . Location of the first three SRWDA's were selected primarily for convenience (Webster, 76). very little geologic or hydrologic considerations were given to the site selections.

As the volume of waste increased, more attention was given to site selection. Areas underlain by Conasauga shale formation make excellent sites for waste disposal, as the shale is easily excavated and has ion exchange properties that inhibit the migration of water-soluble nuclides through the soil. Melton valley is underlain by this formation and is the location of three of the SRWDA's that became operational since 1951. The current operational status and land area of the solid-waste areas are given in Table 1 . Other sources of radioactive contamination on the site include settling basins, impoundments, trenches, and pits.

I'able 1. Operational status of ORNL radioactive solid-waste storage area

\begin{tabular}{lllc}
\hline SRWDA & Eperaring vatés & Status & $\begin{array}{c}\text { Land Used } \\
\text { (acres)* }\end{array}$ \\
\hline & $1943-1944$ & Closed & 1 \\
2 & $1944-1946$ & Closed & 4 \\
3 & $1946-1951$ & Closed & 7 \\
4 & $1951-1959$ & Closed & 23 \\
5 & 1959 & Operating & 33 \\
6 & 1969 & Operating & 68 \\
\hline
\end{tabular}

* One acre $=404 \overline{7} \mathrm{~m}^{2}$. 


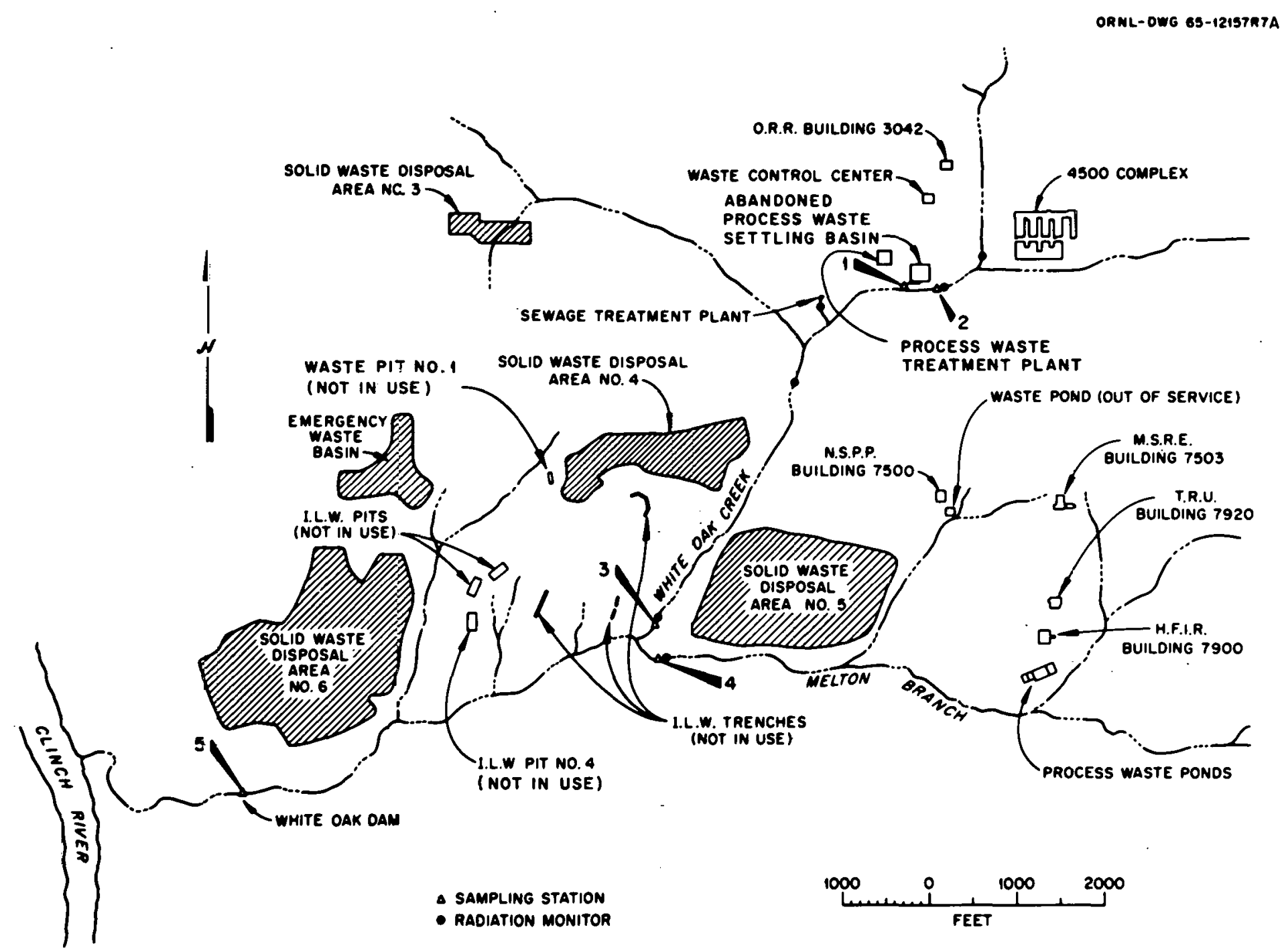

Figure 1. Solid-waste disposal areas and water sampling stations at oRNL. 
SOURCES OF CONTAMINATION

SRWDA No. 1

SRWDA No. 1, with a total area of one acre, is located at the foot of Haw Ridge. It is at the edge of the Laboratory complex and is about 25 feet south of White Oak Creek. This site was selected on the basis of its proximity to the Laboratory; no consideration of waste leaching into the water system was given. Waste was dumped into open trenches and backfilled. There are no available records showing the quantity or kind of solid waste disposed of in these areas. Very little monitoring data is available from SRWDA No. 1 area (Webster, 76). The date of closure of this area was 1944; it was closed because water was found in one of the trenches.

In 1946, the site was surveyed for surface contamination, and soil samples were analyzed. The results from only two areas indicated radioactivity above background levels. Water samples from two wells and a surface seep in this area were analyzed for ${ }^{90} \mathrm{Sr}, 137 \mathrm{Cs}$, and transuranic elements in 1975. Low concentrations of $9^{0} \mathrm{Sr}(9.4 \mathrm{dpm} / \mathrm{ml})$ were present in one of the wells. No detectable quantities of $137 \mathrm{Cs}$ or transuranic elements were found (Duguid, 76).

SRWDA NO. 2

SRWDA No. 2 was operated between 1944-1946, and covered a total area of about four acres. The site is located on the lower half of a hill near the east entrance of the Laboratory. Selection of the site was based primarily on consideration for the reduction of personnel exposure during the transportation of the waste (Webster,76). Very little attention appears to have been given to environmental protection.

There are no available records documenting the quantity or kind of solid waste disposed of in this area. It has been ascertained that solid waste contaminated by beta or gamma activity was placed in black iron drums and buried in the trenches. Liquid waste contaminated by plutonium was placed in stainless steel drums and either buried in trenches or stored without burial in a "natural ravine" eroded in the denuded slope (Webster, 76). 
The use of the SRWDA No. 2 site was later found to be incompatible with the long-range land-use planning at the Laboratory, and the operation was terminated in 1946. After closure, most of the waste was exhumed and reburied in SRWDA No. 3. The stainless steel drums containing liquid plutonium waste were removed intact, but the black iron drums containing beta-gamma solid waste had deteriorated. Thus, the surrounding earth was also removed and reburied at SRWDA No. 3. The hillside of the SRWDA NO. 2 site was then bulldozed to smooth out the irregularities and seeded (Oakes and Shank, 77).

During August 1977, thirteen core samples were collected at various points in SRWDA No. 2. Water samples were also collected from the core holes. Activity levels in water samples were found not to be significantly different from background samples when analyzed for ${ }^{3} \mathrm{H}$, gross-alpha, and gross-beta activity. A representative portion of the homogenized whole core was used for this analysis. The average uranium and plutonium concentrations were found to be $0.47 \mathrm{pCi} / \mathrm{g}$ and $0.06 \mathrm{pCi} / \mathrm{g}$, respectively (Oakes and Shank, 77). The average radioisotope concentration for soil samples near the perimeter of the DOE area in Oak Ridge have been found to contain $0.66 \mathrm{pCi} / \mathrm{g}$ of uranium and $0.04 \mathrm{pCi} / \mathrm{g}$ of plutonium (Oakes, Shank, and Easterly, 76).

The average ${ }^{137} \mathrm{Cs}$ concentration for the upper third and the entire core was measured to be 0.7 and $0.3 \mathrm{pCi} / \mathrm{g}$, respectively. Both of these values are substantially lower than the value of $1.0 \mathrm{pCi} / \mathrm{g}$, the average value of samples collected in 1976 from 16 sites throughout eastern and central Tennessee (Oakes, Shank, and Easterly, 76). It should be noted that these soil samples are from cores several feet long and are being compared with topsoil samples. For ${ }^{90} \mathrm{Sr}$, the average values for the cores were $\leq 0.57$ and $\leq 0.53 \mathrm{pCi} / \mathrm{g}$ for the upper third and the entire core, respectively (Oakes, Shank, and Easterly, 1976).

SRWDA NO. 3

SRWDA No. 3 is about 0.6 miles west of the west entrance to the Laboratory complex. The site is a flat, forested area at the foot of Haw Ridge. Waste Area No. 3 presumably was chosen because of its proximity to the Laboratory, out-of-sight location, and because the soil 
could be readily excavated (Webster, 76). The area became operational in 1946. Alpha-contaminated wastes were dumped in unlined trenches and covered with concrete, whereas the beta-gamma waste was covered with native soil.

Samples of well water from the area were analyzed in 1964 and indicated small amounts of the trivalent rare earths (TRE), ${ }^{0} \mathrm{Sr},{ }^{89} \mathrm{Sr}$, and ${ }^{3} \mathrm{H}$ (Webster, 76). Well samples were also collected in 1973 and analyses indicated ${ }^{90} \mathrm{Sr}$ levels as high as $3.0 \mathrm{dpm} / \mathrm{ml}$. Soil samples were collected and analyzed during 1978, and the results are given in Eldridge et al., (79). The results were found to be higher than natural soil background level (Oakes, Shank, and Easterly, 1976).

\section{SRWDA NO. 4}

During 1948-1950, a study (Stockdale, 51) of the geology and hydrology of the Laboratory site was conducted. Disposal of waste in the Conasauga shale belt was recommended. SRWDA No. 4 was opened in 1951 in the closest area to the Laboratory underlain by Conasauga shale. Trench orientation was variable and lacked any consistent relationship to orginal site topography (Webster, 76). Auger holes one to two feet in diameter were used in this area for the disposal of higher radioactive level waste ( $200 \mathrm{mrem} / \mathrm{hr}$ at surface). The site was closed in 1959 and resulted in a total disposal area of twenty-three acres.

A number of small seeps have developed near the rim of the terrace in the center third of the area, and others are reported to have developed in the central part of the site. During 1959 and 1960, sampling of wells and streams in and near this area indicated that both ground water and surface water were contaminated (Webster, 76). Eight of the sixteen wells showed beta-gamma contamination. Water samples from two seeps indicated contamination of ${ }^{90} \mathrm{Sr},{ }^{137} \mathrm{Cs},{ }^{95} \mathrm{Zr}-95_{\mathrm{Nb}},{ }^{60} \mathrm{Co}$, and TRE. The section of white Oak Creek flowing by SRWDA No. 4 indicated radioactive contaminants of ${ }^{106} \mathrm{Ru},{ }^{90} \mathrm{Sr}, 210^{0} \mathrm{PO}, 239 \mathrm{Pu}$, and TRE. In 1964, water samples were collected from six wells and one seep and each were found to contain $89.90 \mathrm{Sr},{ }^{3} \mathrm{H}, \mathrm{TRE}$, and minor amounts of ${ }^{106} \mathrm{Ru}$ (Webster, 76). Discharges of ${ }^{90} \mathrm{Sr}$ from SRWDA No. 4 versus precipitation are given in Table 2 from Stueber et al. (78). 
Table 2. Strontium-90 discharges versus precipitation

\begin{tabular}{lcc}
\hline Water Year* & $\begin{array}{c}\text { Precipitation } \\
\text { cm }\end{array}$ & $\begin{array}{c}\text { Total } \\
90 \text { Sr Discharge } \\
\text { Ci }\end{array}$ \\
\hline 1967 & 154 & 2.7 \\
1968 & 114 & 2.0 \\
1969 & 102 & 2.1 \\
1970 & 122 & 1.6 \\
1971 & 123 & 1.2 \\
1972 & 120 & 2.4 \\
1973 & 181 & 1.6 \\
1974 & 175 & 5.2 \\
1975 & 147 & 3.2 \\
1976 & 124 & 5.1 \\
1977 & 129 & 2.3 \\
\hline
\end{tabular}

September 1 - August 31 .

Soil samples were collected in 1973 along the south side of SRWDA No. 4. These samples contained small amounts of ${ }^{60} \mathrm{Co},{ }^{137} \mathrm{Cs}$, and ${ }^{90} \mathrm{Sr}$ (Duguid, 76). The soil along white Oak Creek east of the area has been contaminated by seepage from SRWDA No. 4 and discharges of the creek. Near this site is a contaminated flood plain area which was once flooded by an intermediate pond. A dam was constructed in early 1944 to help create an intermediate retention pond between the Laboratory and white Oak Lake. The dam was breached in late 1944, and a small pond remained until 1950 (Duguid, 76). Results of analyses of soil and sediment are given in the section on flood plains.

SRWDA No. 5

SRWDA No. 5 opened in 1959 and consisted of two sections on the hillside east of white Oak Creek and south of Haw Ridge. This area was opened in 1958, because space in SRWDA No. 4 was approaching exhaustion. Initially, the same burial procedures were used at this site as had been used at the preceding sites; that is, alpha-contaminated waste was placed in the lower part of the area and capped with concrete, and the beta-gamma contaminated waste was simply covered with weathered shale. This segregation procedure was discontinued sometime during the operational life of the site. The trench lengths vary from $<40$ feet to $>50$ feet. 
These trenches were oriented parallel to the topographic slopes (Webster, 76). Water samples from several wells were collected in 1964. The principal contaminants found were ${ }^{90} \mathrm{Sr},{ }^{89} \mathrm{Sr},{ }^{106} \mathrm{Ru},{ }^{3} \mathrm{H}$, and TRE. Several new wells were cored and sampled. The data suggested that at this time, only minor movement of radioactivity had occurred. In 1960 , samples from these wells indicated that SRWDA No. 5 was the major source of ${ }^{3} \mathrm{H}$ (Webster, 76) in White oak Creek.

Most of the transport of radionuclides in the surface water is monitored at Station 4 on Melton Branch. Additional data are given in the section on monitoring stations. In 1974, thirteen small seeps were sampled along the south edge of the area. These samples contained measurable amounts of total alpha, ${ }^{90} \mathrm{Sr},{ }^{3} \mathrm{H}$, and ${ }^{125} \mathrm{Sb}$. Eleven of the samples contained concentrations of ${ }^{9}{ }^{0} \mathrm{Sr}$ ranging from $9 \times 10^{-8}$ to $6.1 \times 10^{-5} \mu \mathrm{Ci} / \mathrm{m} \ell$ (Duguid, 76 ).

\section{SRWDA NO. 6}

SRWDA No. 6 is located immediately northwest of White oak Lake. This site is about 70 acres in size and was opened in 1969. Trenches initially were excavated as long as possible, but are now limited to a length of about 50 feet. This procedure was initiated in order to reduce the collection of water in the trenches to an acceptable level. (Webster, 76). Some monitoring around this area has been completed. The results indicate some movement of radioactivity, but it is too early to judge the true meaning of the results.

\section{Floodplain Areas}

There are four floodplain areas on the site that are contaminated. For the purposes of this paper, only the floodplain that was established by the construction of the dam in 1944 will be discussed.

During 1974, a study of the ${ }^{137} \mathrm{Cs}$ distribution in soil, roots, ground vegetation, overstory, litter, mammals, flies, and insert.s from the 2 ha $\left(20,000 \mathrm{~m}^{2}\right)$ flood plain area was made (Voris and Dahlman, 76). The highest concentration found in soil was $84,400 \mathrm{pCi} / \mathrm{g}$. All $137 \mathrm{Cs}$ concentrations below the $17-\mathrm{cm}$ depth, outside the floodplain area were 
equal to background. Concentrations in the roots ranged as high as $12,500 \mathrm{pCi} / \mathrm{g}$. The concentration of ${ }^{137} \mathrm{Cs}$ in ground vegetation ranged from 4.6 to $182 \mathrm{pCi} / \mathrm{g}$. Other results can be found in Voris and Dahlman (76).

\section{Waste Ponds}

Another source of radioactive discharges from past waste treatment procedures are the waste ponds. Three waste ponds have been in use at ORNL. An example of the activity in these ponds is from a study in 1977 (Tamura, Sealand, and Duguid, 77) of Waste Pond 2. This study indicated approximately $5 \mathrm{Ci}$ of $239,240 \mathrm{Pu}, 200 \mathrm{Ci}$ of ${ }^{137} \mathrm{Cs}$, and $33 \mathrm{Ci}$ of ${ }^{90} \mathrm{Sr}$ in the bottom sediment. Another source of discharged waste is the Intermediate-Level Waste Pits.

\section{Seepage Pits and Trenches}

In 1951, the construction of pits for disposal of intermediatelevel 1 iquid was begun. The first pit was opened in 1951 and immediately closed because of its poor location. The second pit was opened in 1952, and large quantities of intermediate-level waste were disposed of for the first time. Pits 3 and 4 became operational in 1955 and 1956, respectively. Trenches 5, 6, and 7 were opened between 1960-1962. These trenches were taken out of routine service in 1965 as part of a plan to implement disposal of intermediate-level waste by hydrofracture (Duguid, 75).

Small amounts of ${ }^{90} \mathrm{Sr}$ and ${ }^{137} \mathrm{Cs}$ have been observed in seepage from trenches 6 and 7 . The major seepage problem has been with ${ }^{106} \mathrm{Ru}$, as seen in Table 3.

Table 3. Annual discharges of ${ }^{106} \mathrm{Ru}$ to the Clinch River

\begin{tabular}{lrrr}
\hline Year & Ci & Ycar & Ci \\
\hline 1959 & 520 & 1965 & 69 \\
1960 & 1900 & 1966 & 29 \\
1961 & 2000 & 1967 & 17 \\
1962 & 1400 & 1968 & 5 \\
1963 & 130 & 1969 & 2 \\
1964 & 191 & 1970 & 1 \\
\hline
\end{tabular}


WATER SAMPLING

Low-level radioactive liquid wastes originating from ORNL operations are discharged, after preliminary treatment, to white oak Creek and Melton Branch, which are small tributaries of the Clinch River. The radioactive content of the white oak Creek discharge is determined at White Oak Creek Stations 1, 2, and 3 and at White Oak Dam, which is the last control point along the stream prior to the entry of white oak Creek into the Clinch River. Samples are collected at several locations in the clinch River, beginning at a point above the entry of the wastes into the.river and ending at Center's Ferry near Kingston, Tennessee, the nearest population center downstream. Location maps of these stations are given in Figures 1 and 2 .

\section{Station 1}

White Oak Creek Station 1 monitors the effluent from the ORNL Process Waste Treatment Plant.

\section{Station 2}

Station 2 is located on white Oak Creek a short distance upstream from Station 1 and provides data on radionuclide content from operational discharges above the Process waste Treatment Plant.

\section{Station 3}

Water Monitoring Station 3 is located on white Oak Creek a short distance above the confluence of white Oak Creek and Melton Branch. This station measures the streamflow and radionuclides content from the ORNL plant effluents; seepage from SRWDA Nos. 1, 2, 3, 4, and a portion of 5; contaminated floodplain sediments; and other potential sources.

\section{Station 4}

Station 4 is located on Melton Branch, a short distance above the confluence with white Oak Creek. This station measures streamflow and radionuclide content from SRWDA No. 5, several experimental reactor sites, and other areas. 


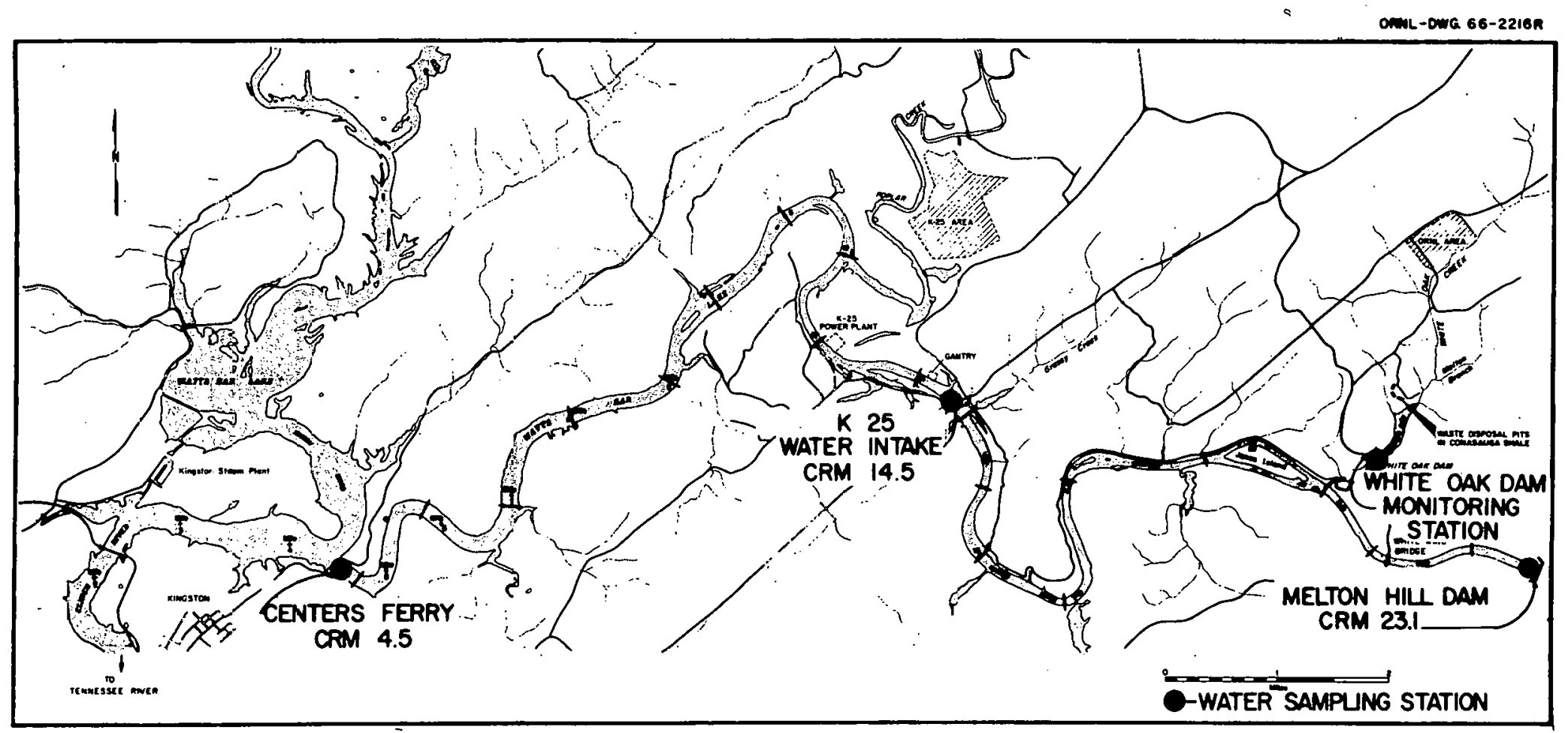

Figure 2. Water monitoring locations in the Clinch River. 


\section{Station 5}

Samples of White Oak Creek effluent are collected at White Oak Dam by a continuous proportional sampler which was designed and constructed at ORNL. Proportional sampling is necessary to obtain a truly representative sample, since streamflow and concentration of radioactive materials in the stream may vary independently over a relatively wide range in a relatively short period of time, depending upon weather and operating conditions. Streamflow at white Oak Dam is measured by means of a Stevens water-level recorder and stilling well in the lake pool in conjunction with the White Oak Dam gate, which serves as a rectangular weir through which the water flows (Oakes and Shank, 78). The weir system was rated by the U.S. Geological Survey and found to be accurate to within $5 \%$.

Samples are collected weekly from white oak Dam and analyzed for gross beta activity as a control measure and as a means of evaluating the gross concentration of radioactivity entering the clinch River. Portions of the weekly samples are composited, proportional to the flow, into monthly composite samples that are subjected to more detailed analyses by wet chemical and gamma spectrometric techniques. The weekly samples are analyzed for the transuranic alpha emitters, total strontium, and ${ }^{131} I$, which represent the elements in the waste stream with the highest hazard indices.

The monthly composites are concentrated and analyzed by radiochemical and gamma spectrometric techniques, normally for the following radionuclides: ${ }^{9}{ }^{0} \mathrm{Sr},{ }^{13 \%} \mathrm{Cs},{ }^{131} \mathrm{I},{ }^{106} \mathrm{Ru},{ }^{6} \mathrm{U}_{\mathrm{CO}}, 3_{\mathrm{H}}$, transuranics, and gross beta. Analyses for other nuclides may be performed as the need arises. These analyses are performed to determine the percentage distribution and concentrations of the various nuclides in the effluent stream and to calculate the quantity of each radionuclide released to the Clinch River. More frequent analyses are made if concentration levels in white Oak Creek vary siqnificantly from the experienced normal.

Calculations are made of the concentrations of radioactivity in the Clinch River, using the concentrations measured at white Oak Dam and the dilution provided by the River. These calculations are based on uniform 
mixing of the two streams within a short distance downstream from the point of entry of the wastes. The calculated concentration of each radionuclide in the river is compared with its respective $M P C_{w}$ value as specified by Chapter 0524 of the DOE Manual and the resulting fractions are summed to arrive at the $8 \mathrm{MPC}$ in the Clinch River.

The annual discharges of radionuclides to the Clinch River as measured at white Oak Dam from 1949-1978 are given in Table 4. The measured $\mathrm{MPC}_{\mathrm{w}}$ at White Oak Dam and the calculated $\mathrm{MPC}_{\mathrm{w}}$ in the Clinch River from 1974-1978 are given in Figures 3 and 4, respectively. The total amount of radionuclides discharged into the Clinch River is given in Table 5. The amount of ${ }^{3} \mathrm{H}$ released to the river in three-year periods from 1965-1977 is given in Figure 5.

As a followup to this calculated concentration, two sampling stations are maintained in the Clinch River below the point of entry of the wastes: one at the ORGDP water intake, Clinch River mile (CRM 14.5), and the other at Center's Ferry near Kingston, Tennessee (CRM 4.5). In addition, a sampling station is maintained in the Clinch River above the point of entry of the waste at Melton Hill Dam (CRM 23.1) to provide background data.

\section{ORGDP Water Intake Sampling Station}

The ORGDP water sampling station, which was designed and constructed at ORNL, collects a sample from the Clinch River that is proportional to the flow in the river near the water intake of the ORGDP plant water system (the first point of Clinch River water usage downstream from the point of entry of ORNL wastes). The samples are brought into the laboratory at weekly intervals, acidified, and combined into quarterly composite samples for analysis. The quarterly composite samples are concentrated by evaporation and analyzed by wet chemical and gamma spectrometric techniques for gross activity and for ${ }^{90} \mathrm{Sr},{ }^{137} \mathrm{Cs},{ }^{106} \mathrm{Ru},{ }^{60} \mathrm{Co}$, ${ }^{95} \mathrm{Zr}$, and ${ }^{3} \mathrm{H}$. The percent $\mathrm{MPC}_{\mathrm{w}}$. total for the mixture is calculated from the concentration values measured. The $\mathrm{MPC}_{\mathrm{w}}$ at this point from 1974-1978 are given in Figure 6. 
Table 4. Annua: discharges of radionuclides to the Clinct. River, 1949 to Ig78. Curies

\begin{tabular}{|c|c|c|c|c|c|c|c|c|c|c|c|c|c|c|}
\hline year & ${ }^{137} \mathrm{Cs}$ & ${ }^{105} \mathrm{Ru}$ & ${ }^{89} \mathrm{Sr}$ & ${ }^{90} \mathrm{Sr}$ & $\operatorname{TRE}^{\star}(-\mathrm{Ce})$ & ${ }^{144} \mathrm{Ce}$ & $\varsigma_{z x}$ & $95_{\mathrm{Nb}}$ & ${ }^{131} I$ & ${ }^{61} \mathrm{CO}$ & ${ }^{3} \mathrm{H}$ & & TRU & \\
\hline 1949 & 77 & 110 & & 150 & 77 & 18 & 180 & 22 & 77 & & $N A$ * * & & 0.009 & (from $8 / 12 / 49$ ) \\
\hline 1950 & 19 & 23 & & 38 & 30 & NA & 15 & 42 & 19 & & & & 0.04 & ! \\
\hline 1951 & 20 & 18 & & 29 & 11 & NA & 5 & 2 & 18 & & & & 0.08 & \\
\hline 1952 & 10 & 15 & & 72 & 26 & 23 & 19 & 18 & 20 & & & & 0.03 & \\
\hline 1953 & 6 & 26 & & 130 & 110 & 7 & 8 & 4 & 2 & & & & 0.08 & \\
\hline 1954 & 22 & 11 & & 140 & 160 & 24 & 14 & 9 & 4 & $\mathbf{A A}_{\mathbf{A}}$ & & & 0.07 & \\
\hline 1955 & 63 & 31 & & 93 & 150 & 85 & 5 & 6 & 7 & $?$ & & & 0.25 & \\
\hline 1956 & 170 & 29 & & 100 & 140 & .59 & 12 & 15 & 4 & 4.6 & & & 0.28 & \\
\hline 1957 & 89 & 50 & & 83 & 110 & 13 & 23 & 7 & 1 & 5 & & & 0.15 & \\
\hline 1958 & 55 & 42 & NA & 150 & 240 & 30 & 6 & 6. & 8 & 9 & & & 0.08 & \\
\hline 1959 & 76 & 520 & 0.3 & 60 & 94 & 48 & 27 & 30 & 1 & $\because 7$ & & & 0.68 & \\
\hline 1960 & 31 & 1900 & 1.9 & 28 & 48 & 27 & 38 & 45 & 5 & $\because 2$. & & & 0.19 & \\
\hline 1961 & 25 & 2000 & 2.0 & 22 & 24 & 4 & 20 & 70 & 4 & $\because 1$ & & & 0.07 & \\
\hline 1962 & 6 & 1400 & 1.7 & 9 & 11 & $i$ & 2 & 8 & 0.4 & $=4$ & & & 0.06 & \\
\hline 1963 & 4 & 430 & 1.0 & 8 & 9 & 2 & 0.3 & 0.7 & 0.4 & $=4$ & & & 0.17 & \\
\hline 1964 & 6 & 191 & 0.8 & 7 & 13 & 0.3 & 0.2 & 0.1 & 0.3 & $=5$ & 1929 & & 0.08 & \\
\hline 1965 & 2 & 59 & 0.6 & 3 & 6 & 0.1 & 0.3 & 0.3 & 0.2 & $=2$ & 1161 & & 0.50 & \\
\hline 1966 & 2 & 29 & 0.9 & 3 & 5 & 0.1 & 0.7 & 0.7 & 0.2 & $?$ & 3090 & & 0.16 & \\
\hline 1967 & 3 & 17 & 0.7 & 5 & 9 & 0.2 & 0.5 & 0.5 & 0.9 & 3 & 13273 & & 1.03 & \\
\hline 1968 & 1 & 5 & 0.6 & 3 & 4 & 0.03 & 0.3 & 0.3 & 0.3 & 1 & 9685 & & 0.04 & \\
\hline 1969 & 1 & 2 & 10.3 & 3 & 5 & 0.02 & 0.2 & 0.2 & 0.5 & 1 & 12247 & & 0.20 & \\
\hline 1970 & 2 & 1 & 0.3 & 4 & 5 & 0.06 & 0.02 & $0.0 z$ & 0.3 & 1 & 9473 & & 0.40 & \\
\hline 1971 & 1 & 0.5 & 0.2 & 3 & 3 & 0.05 & $0.0=$ & 0.01 & 0.2 & 1 & 8945 & & 0.05 & \\
\hline 1972 & 2 & 0.5 & $N A^{* \star}$ & 6 & 5 & 0.03 & 0.0 & $0.0 \mathrm{~J}$ & 0.3 & 1 & 10600 & & 0.07 & \\
\hline 1973 & 2 & 0.7 & & 7 & NA & 0.02 & 0.05 & 0.05 & 0.5 & 1 & 15000 & & 0.08 & \\
\hline 1974 & 1 & 0.2 & & 6 & & 0.02 & 0.02 & 0.02 & 0.2 & 0.5 & 8633 & & 0.02 & \\
\hline 1975 & 0.6 & 0.3 & & 7 & & NA & NA & NA & 0.3 & 0.5 & 11061 & & 0.02 & \\
\hline 1976 & 0.2 & 0.2 & & 5 & & & & & 0.03 & 0.7 & 7422 & & 0.01 & \\
\hline 1977 & 0.2 & 0.2 & & 3 & & & & & 0.03 & 0.2 & 6249 & . & 0.03 & \\
\hline 1978 & 0.3 & 0.2 & & 2 & & & & & 0.04 & 0.7 & 6292 & & 0.03 & \\
\hline
\end{tabular}

Total rare earths minus cerium

** No analysis performed. 


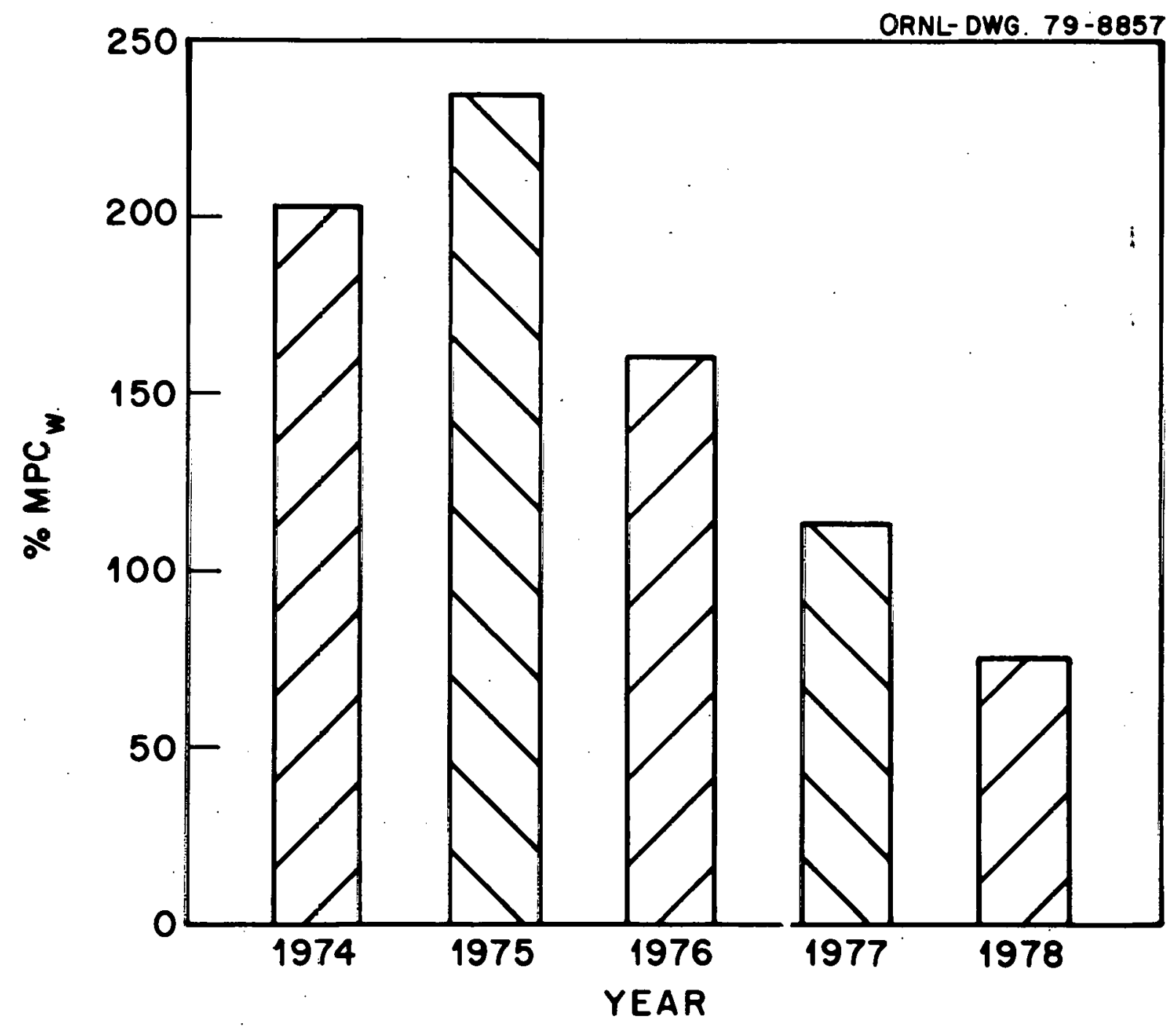

Figure 3. Percent of $M P C_{w}$ total over White Oak Dam. 


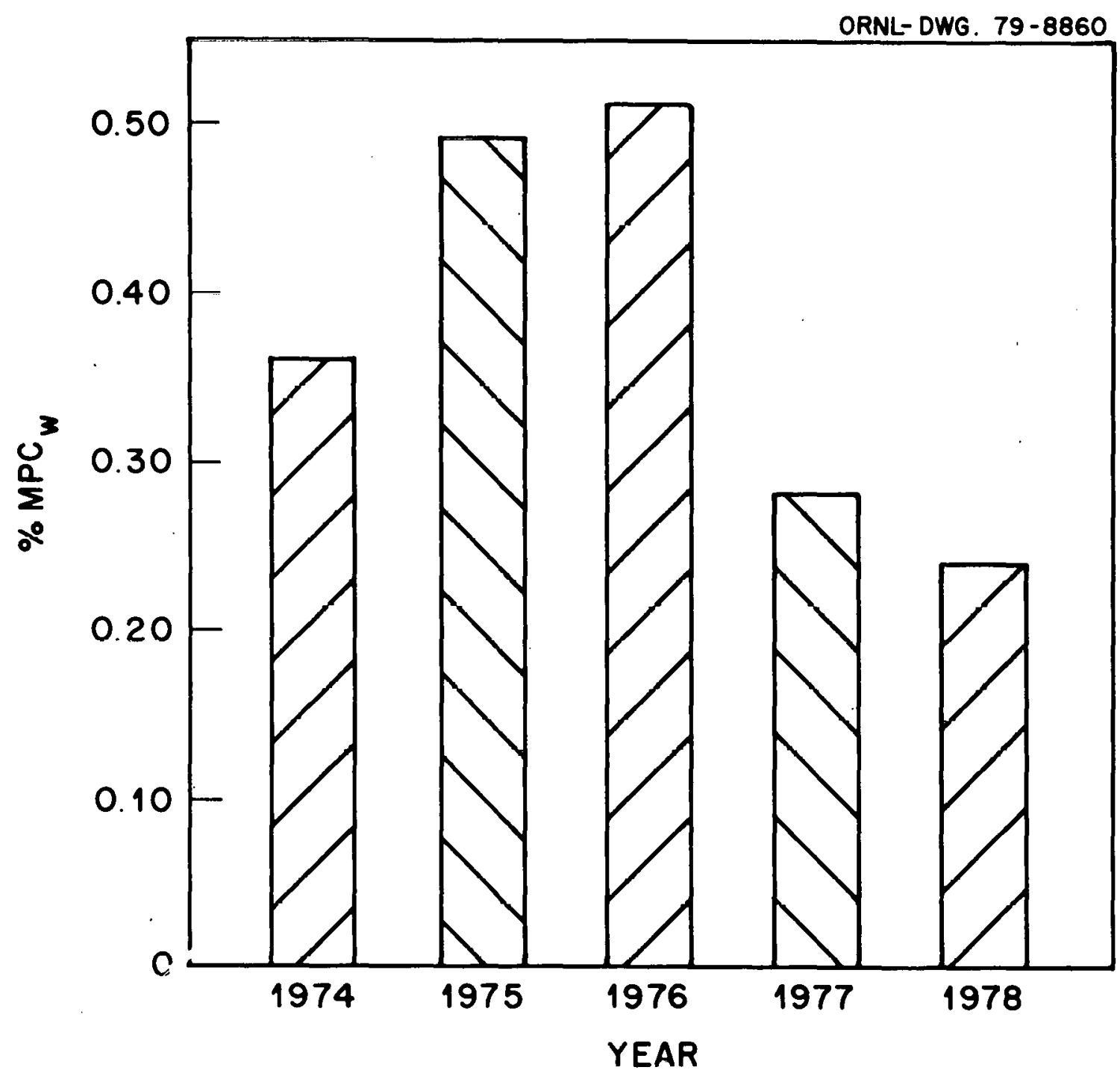

Figure 4. Percent of $M P C_{W}$ total for dilution calculation in the Clinch River. 
Table 5. Total amount of radionuclides discharged into Clinch River $1949-1978$

\begin{tabular}{ccr}
\hline Time Interval & Radionuclide & $\mathrm{Ci}$ \\
\hline $1949-78$ & $9{ }^{0} \mathrm{Sr}$ & 1,179 \\
$1949-78$ & $95^{5} \mathrm{Nb}$ & 286 \\
$1949-78$ & $95^{\mathrm{Zr}}$ & 375 \\
$1949-78$ & $106{ }_{\mathrm{Ru}}$ \\
$1949-78$ & $131_{\mathrm{I}}$ & 6,932 \\
$1949-78$ & $137_{\mathrm{Cs}}$ & 174 \\
$1964-78$ & ${ }^{3} \mathrm{H}$ & 687 \\
$1955-78$ & $60^{0} \mathrm{Co}$ & 321,945 \\
$1949-74$ & $14{ }^{14} \mathrm{Ce}$ & 342 \\
$1949-71$ & TRE $(-\mathrm{Ce}) *$ & 1,289 \\
\hline Trivalent rare earths minus cerium. &
\end{tabular}




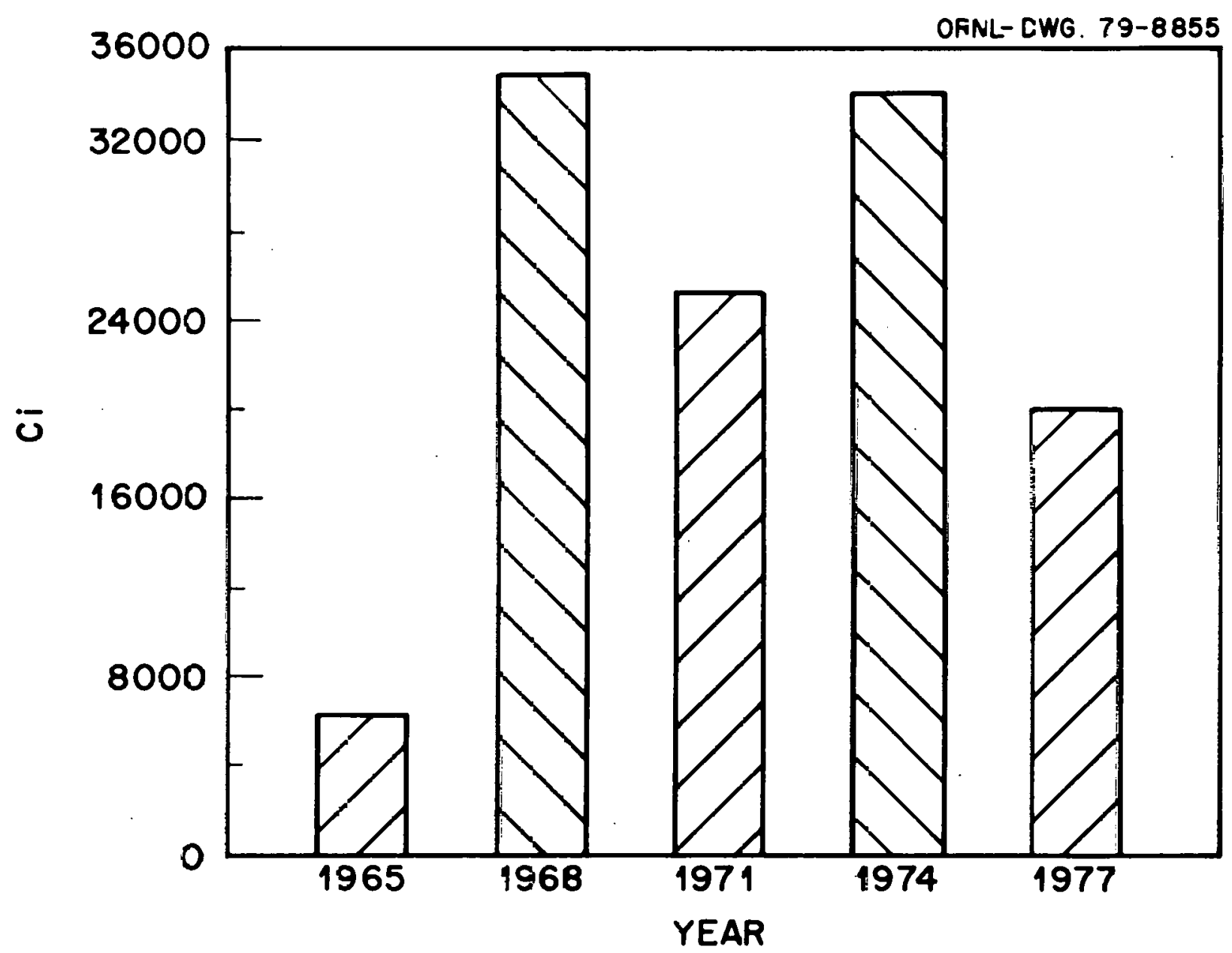

Figure 5. Tritium releases to the Clinch River (3-yr. intervals). 


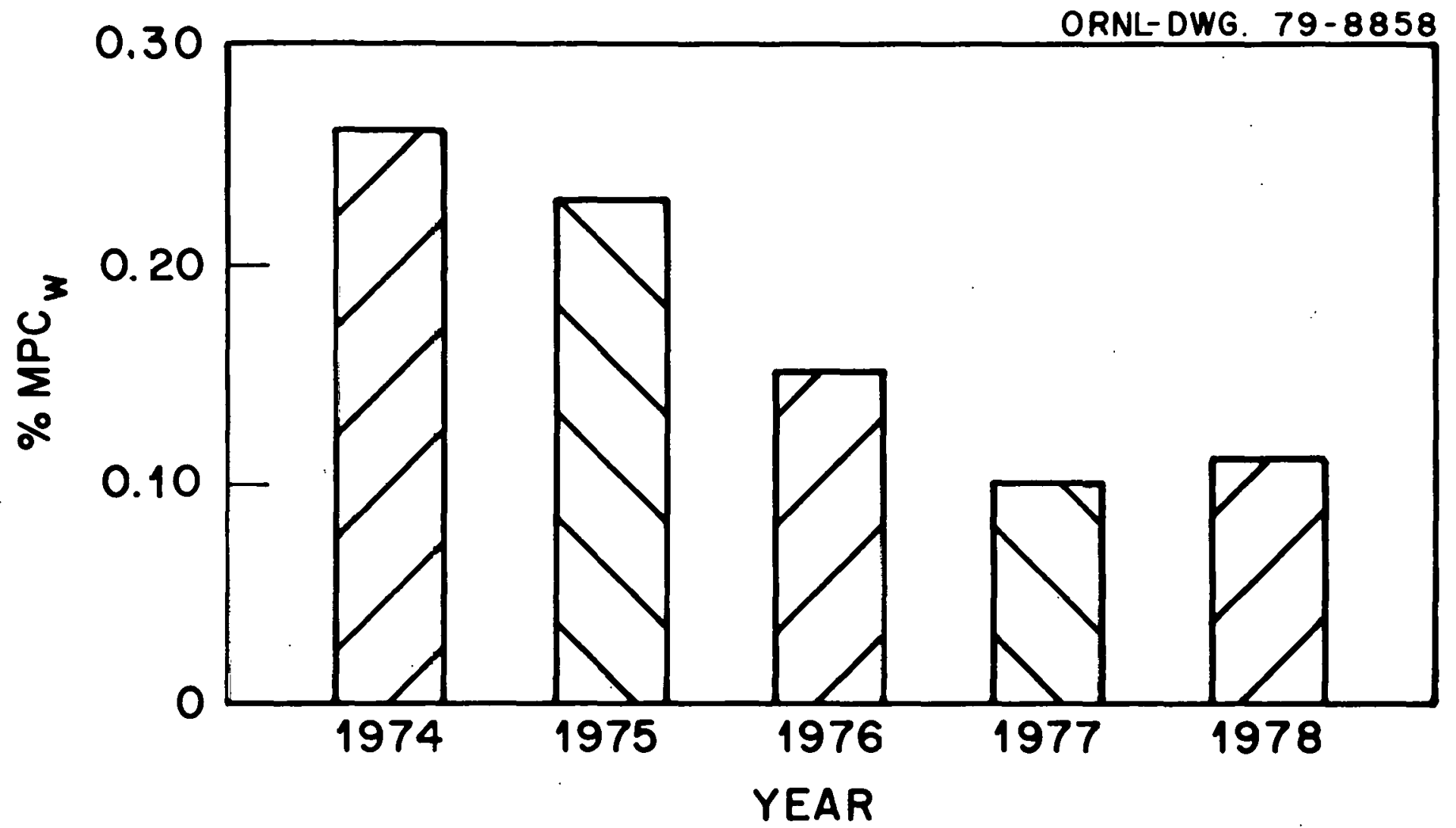

Figure 6. Percent of $\mathrm{MPC}_{\mathrm{w}}$ total at the ORGDP intake. 
The ORGDP sampling station was established to provide data relative to the concentrations of radioactivity in water taken from the Clinch River for normal treatment plant usage, to provide an index of the hazard to the ORGDP plant population as the first user of Clinch River water downstream from the point of entry of the ORNL wastes, and to provide data for comparison with the concentrations in the Clinch River calculated from White Oak Dam releases and the dilution provided by the river.

\section{Center's Ferry Sampling Station}

A "qrab" sample is collected daily at the Center's Ferry samping station which is located on the Clinch River at CRM 4.S. Thermal stratification exists at this location, with the cold water of the clinch kiver running under the warmer backwater of the watts Bar Reservoir. The sample is collected 25 feet below the surface of the water to ensure the collection of $\mathrm{Clinch}$ River water for the sample. Fluctuations in concentration at this location are relatively small due to the distance downstream from the point of entry of the wastes, and dispersion of radioactivity in the Clinch River water is complete; thus a grab sample is considered adequate. The daily grab samples are composited, acidified, and analyzed on a quarterly basis. The preparation of the sample and the analyses performed are the same as those clted for the ORGDP water. sampling station.

Samples from the Center's. Ferry sampling station provide data relative to the average concentration of radioactive materials in the Clinch River at the nearest population center (Kingston, Tennessee) downstream from the point of entry of the wastes. The $M C_{w}$ from 1976-1978 is given in Figure 7. A comparison of the calculated MPC ${ }_{w}$ at ORGDP and Center's Ferry is given in Table 6.

Table 6. Tutal percent MPC in the Clinch River

\begin{tabular}{llll}
\hline Year & ORDGP & $\begin{array}{c}\text { Center's } \\
\text { Ferry }\end{array}$ & $\begin{array}{c}\text { Calculated } \\
\text { Clinch River* }\end{array}$ \\
\hline 1974 & 0.268 & 0.218 & 0.368 \\
1975 & 0.23 & 0.15 & 0.49 \\
1976 & 0.15 & 0.15 & 0.51 \\
1977 & 0.10 & 0.12 & 0.28 \\
1978 & 0.11 & 0.12 & 0.24 \\
\hline
\end{tabular}

${ }^{*}$ Calculated concentrations in Clinch River using dilution factors. 


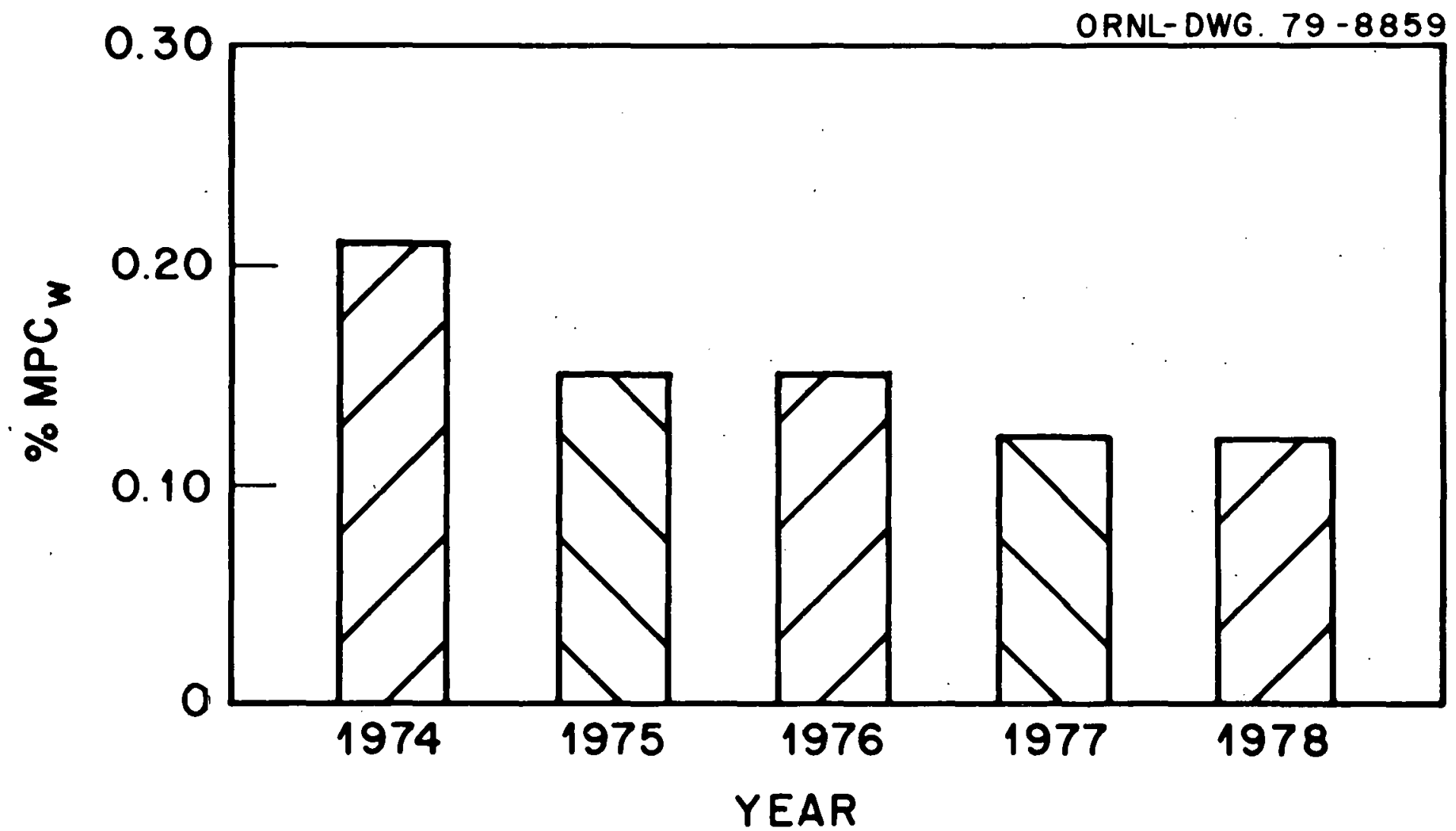

Figure 7. Percent of $\mathrm{MPC}_{\mathrm{w}}$ total at Kingston, Tennessee. 
Melton Hill Dam Sampling Station

The Melton Hill Dam sampling station collects a sample proportional to the flow of water through the power-generating turbine, which represents all of the discharge from the Dam other than a minor amount discharged in the operation of the lock. The sampler was designed and constructed at ORNL and is located on the lower side of the Dam, with the intake positioned at the tail race of the turbines. The sampler is keyed to the turbine operation such that a sample is collected only when the turbines are operating, even though water from the tail race is continuousiy pumped through the sampiing lines. Samples are collected from the station at weekly intervals, aciditied, and composited for a quarterly period in polyethylene containers. The quarterly sample is processed and analyzed in the manner set forth (above) for the ORGDP water sampling station.

In addition to meeting routine monitoring requirements, water monitoring aids in the detection of abnormalities. For example, in 1969, high levels of ${ }^{60} \mathrm{Co}$ were detected in the water at Melton Hill (CRM 23.1). River silt was then analyzed and found to contain $16 \mathrm{pCi} / \mathrm{g}$ of ${ }^{60} \mathrm{Co}$ above Melton Hill. Concentration below ORNL discharges was $1.2 \mathrm{pCi} / \mathrm{g}$ (CRM 19.1). Investigation resulted in the finding of a waste tank leak at American Nuclear Corporation located at approximately CRM 51. 
OTHER ENVIRONMENTAL ANALYSIS

Other types of samples such as sediment and fish are also collected for the purpose of monitoring the discharges from the plant site.

\section{Fish Sampling.}

Several species of $\mathrm{fish}$ from the Clinch River are sampled. Ten fish of each species are composited for each sample, and the samples are analyzed by gamma spectrometry and radiochemical techniques for the critical radio nuclides that contribute to dose. A conservative upper limit estimate of man's intake of radionuclides from eating the fish is made by assuming an annual rate of fish consumption of 37 pounds. The estimated percentage of MPI is calculated by assuming a maximum permissible intake of fish to be comparable to daily intake of 2.2 liters of water containing the $\mathrm{MPC}_{\mathrm{w}}$ of these radionuclides for a period of one year. The highest recorded MPI in the last 15 years for any species has been $8.1 \%$.

Sediment Sampling

Annual average concentrations of radionuclides in the uppermost layers of bottom sediments in the Clinch and Tennessee Rivers were conducted from 1951-1969. This information is relevant to the dispersal and movement of radioactivity released from ORNL. Data varied from year to year with the changes in the amounts of radionuclides released. The principal radionuclide contained in the bottom sediments is ${ }^{137} \mathrm{Cs}$ with lesser amounts of ${ }^{60} \mathrm{Co},{ }^{106} \mathrm{Ru}$, and ${ }^{144} \mathrm{Ce}$ being retained. Only a small amount of ${ }^{90} \mathrm{Sr}$ is either in solution or associated principally with suspended solids and, thus, passes through the river system. Sediment data can indicate discharges as shown in Figure 8. 


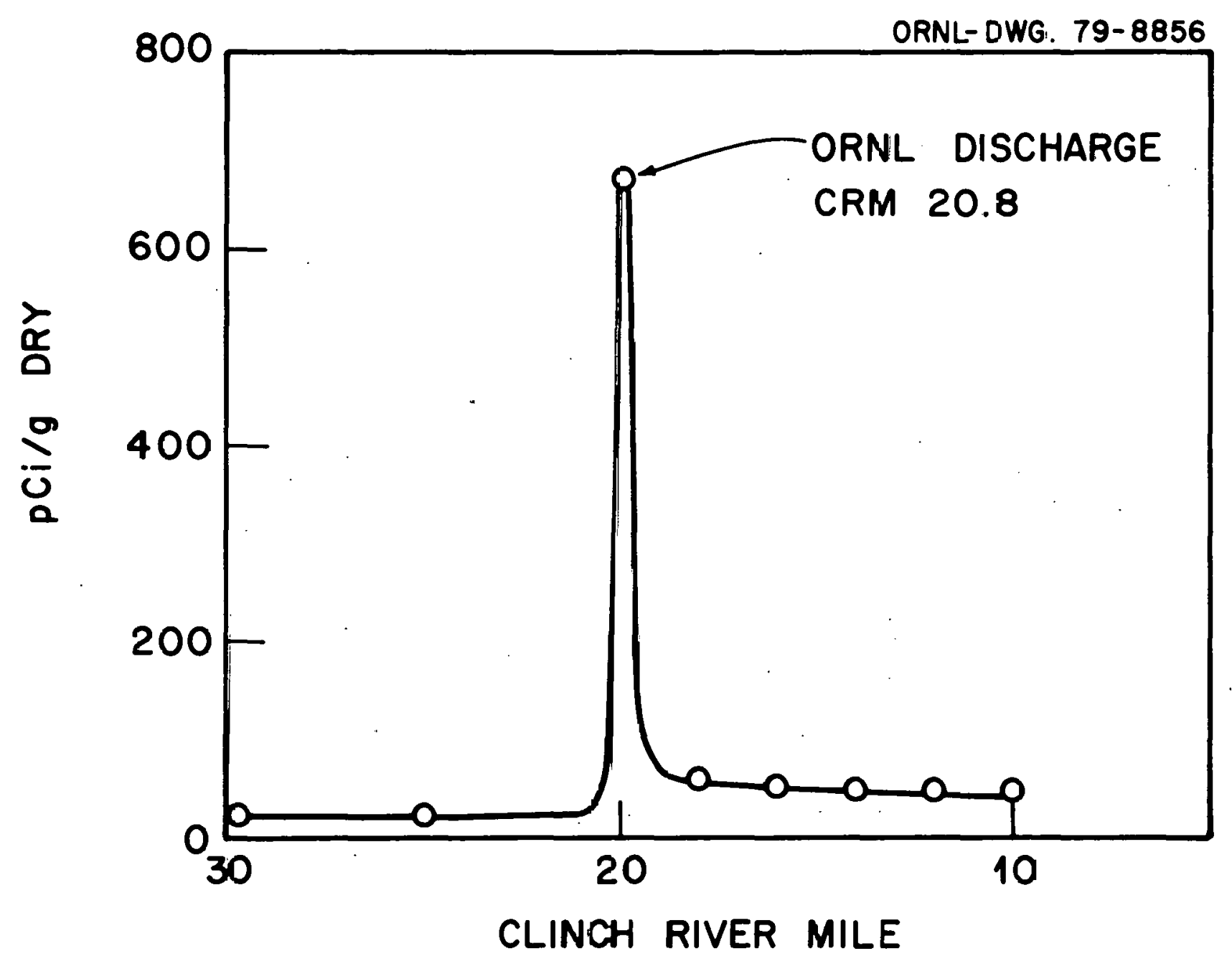

Figure 8. Cesium-137 in river silt (196.7). 


\section{CONCLUSIONS}

I. Facts with regard to the releases from ORNL waste practices over the last twenty years.

A. Ruthenium Releases.

1. A large amount of ruthenium was released during 1959-64. This reflected the seepage of ${ }^{106}$ Ru from the ILW waste -pit disposal area following the transfer of a large quantity of material to the pit in 1959.

2. The Conasauga shale did not retain ruthenium as well as other radionuclides.

B. Tritium Releases.

1. Large quantities of tritium have been released to the Clinch River in recent years.

2. Origin of the bulk of the tritium is apparently the burial grounds where tritium-bearing waste from another laboratory was buried.

3. From a practical economical standpoint, little can be done to inhibit or control these releases.

C. There has been a downward trend in the number of curies released for all other radionuclides.

\begin{tabular}{ccl} 
Radionur:1ines & \multicolumn{2}{c}{$\mathrm{Ci}$} \\
\cline { 2 - 3 } 1959 & $\underline{1978}$ \\
${ }^{60} \mathrm{Co}$ & 77 & 0.4 \\
$9^{0} \mathrm{Sr}$ & 60 & 2.0 \\
$131_{\mathrm{I}}$ & 0.5 & 0.04 \\
$137_{\mathrm{Cs}}$ & 76 & 0.3
\end{tabular}

II. A number of corrective measures have been taken at ORNL to reduce the discharges. Some of these are:

A. The method of disposal of liquid waste into pits and trenches was discontinued in 1965, and the use of hydrofracture was begun in 1966.

B. Rerouting of White oak Creck to bypass flood plain areas. 
c. The installation of the new Process waste Treatment Plant which became operational in April, 1976, has significantly reduced the ${ }^{90} \mathrm{Sr}$ discharges to white oak creek from facility operations.

D. Paved intercepter ditches have been placed in the burial ground area to control the surface runoff in that area and reduce percolation.

E. Hydrological considerations are being reviewed in the selection of a new hurial site.

F. Small trenches are being used to reduce the amount of water collected in them after disposal has occurred.

G. Volume reduction programs have been initiated. Better monitoring programs are also being initiated. Other proposed corrective measures for the reduction of releases and proposed facilities for the disposal of low-level waste are being considered. These efforts have resulted in a reduction in the diooharges from lle slle as has been shown in this paper. 
REFERENCES

Duguid, J. O., Status Report on Radioactivity Movement from Burial Grounds in Melton and Bethel Valleys, ORNL-5017 (1975).

Duguid, J. O., Annual Progress Report of Burial Ground Studies at Oak Ridge National Laboratory, Period Ending September 30, 1975, ORNL-5141 (1976).

Eldridge, J. S., Oakes, T. W., Shank, K. E. and Stueber, A. M., "Instrumental Methods Used in Environmental Surveillance Programs Around a Low-Level Radioactive Burial Site," presented at the Twelfth Midyear Topical Symposium of the Health Physics Society, Williamsburg, virginia, February 12-15, 1979.

Oakes, T. W., Shank, K. E., and Easterly, C. E. "Natural and Man-Made Radionuclide Concentrations in Tennessee Soils" in Proceedings of the Tenth Midyear Topical Symposium of the Health Physics Society, Saratoga Springs, New York, October 11-13, 1976.

Oakes, T. W., and Shank, K. E. Subsurface Investigation of the Energy System Research Laboratory Site at Oak Ridge National Laboratory, ORNL/TM-5695 (1977).

Oakes, T. W. and Shank, K. E., "Application of a Microprocessor System to Stream Monitoring," in Proceedings of the Eleventh Midyear Topical Symposizm on Radiation Instmmentation, San Diego, California, January 16-19, 1978.

Stockdale, P. B., Geological Conditions at the Oak Ridge National Laboratory $(X-10)$ Area Relevant to the Disposal of Radioactive Waste, ORO-58 (1951).

Stueber, A. M., Edgar, D. E., McFadden, A. F., and Scott, T. G., Plieliminury Inveotigation of ${ }^{90}$ Sr in. White oak Creek Between Monitoring Stations 2 and 3, Oak Ridge National Laboratory, ORNL/TM-6510 (1978).

Tamura, T., Sealand, O. M., and Duguid, J. O., Preliminary Inventory of $239.240 \mathrm{Pu},{ }^{90} \mathrm{Sr}$, and ${ }^{137} \mathrm{Cs}$ in Waste Pond No. 2(3513), ORNL/TM-5802 (1977).

Webster, D. A., A Review of Hydrologice and Geologic Conditions Related to the Radioactive Solid-Waste Burial Grounds at Oak Ridge National Luburutory, Oak Ridgo, Tennessee, Open File Report 76-727, U.S. Department of the Interior, Geological Survey, 1976.

Voris, P. V., and Dahlman, R. C., Floodplain Data: Ecosystem Characteristics and ${ }^{137} \mathrm{Cs}$ Concentrations in Biota and Soil, ORNL/TM-5526 (1976). 
THIS PAGE

WAS INTENTIONALLY

LEFT BLANK 
INTERNAL DISTRIBUTION

ORNL/TM-6893

$\begin{array}{ll}\text { 1. S. I. Auerbach } \\ \text { 2. J. A. Auxier } \\ \text { 3. T. J. Burnett } \\ \text { 4. } & \text { K. E. Cowser } \\ \text { 5. } & \text { D. M. Davis } \\ \text { 6. C. E. Easterly } \\ \text { 7. } & \text { J. S. Eldridge } \\ \text { 8. M. F. Fair } \\ \text { 9. J. A. Horak } \\ \text { 10. S. V. Kaye } \\ \text { 11. B. A. Kelly } \\ \text { 12. E. M. King } \\ \text { 13. A. L. Lotts } \\ \text { 14. C. W. Miller } \\ \text { 15. M. A. Montford }\end{array}$
16-47. T. W. Oakes

48. D. C. Parzyck

49. C. R. Richmond

50. R. A. Robinson

51. P. Rohwer

52. T. G. Scott

53-79. K. E. Shank

80. D. B. Trauger

81. F. S. Tsakeres

82. E. B. Wagner

83-84. Central Research Library

85. Document Reference Section ORNL Y-12. Technical Library

86-87. Laboratory Records Department

88. Laboratory Records, ORNL RC

89. ORNL Patent Office

EXTERNAL DISTRIBUTION

90. H. H. Abee, UCC-ND Office of Health, Safety, and Environmental Affairs, Oak Ridge, Tennessee 37830

91. L. J. Deal, Department of Energy, Washington, D.C. 20545

92. D. Fehringer, Nuclear Regulatory Commission, Washington, D.C. 20555

93. H. W. Hibbitts, Department of Energy - Oak Ridge Operations, Oak Ridge, Tennessee 37830

94. H. Hollister, Department of Energy, Washington, D.C. 20545

95. W. J. McCool, Department of Eniergy, Washjngton, D.C. 20545

96. J. W. Peel, Department of Energy - Idaho Operations office, Idaho Falls, Idaho 83401

97. D. M. Ross, Department of Energy, Washington, D.C. 20545

98. W. D. Travers, Nuclear Regulatory Commission, washington, D.C. 20555

99. J. F. Wing, Department of Energy - Oak Ridge Operations, Oak Ridge, Tennessee 37830

100. Office of Assistant Manager, Energy Research and Developipment, Department of Energy - Oak Ridge Operations, Oak Ridge, Tennessee 37830

101-127. Technical Information Center, DOE-ORO, Oak Ridge, Tennessee 37830 